\title{
A Functional Approach to the Applicability of Section 553 of the Administrative Procedure Act to Agency Statements of Policy
}

A large gap often exists between a federal administrative agency's understanding of its law and policy and the understanding of outsiders.' Two of the principal means available to agencies for structuring their discretionary power through policy making, ${ }^{2}$ and thereby closing this gap, are the issuance of policy statements and rules. ${ }^{3}$ A general policy statement is usually less structured than a rule and may reflect the agency's belief that its policy is not yet ripe enough to be formalized in a rule. ${ }^{4}$ Since general statements of agency policy can be issued in any form ${ }^{5}$ and may not come to the attention of affected private parties, ${ }^{6}$ the need exists for a mechanism by which policy statements with more definite standards can be developed and publicized. Such a mechanism is available to agencies in the form of administrative rulemaking ${ }^{7}$ under the noticeand-comment procedures of section 553 of the Administrative Procedure Act (APA), ${ }^{8}$ which were largely designed to facilitate the

I See K. Davis, Discretionary Justice: A Preliminary Inquiry 102 (1960) [hereinafter cited as Discretionary Justice]; Baker, Policy by Rule or Ad Hoc Approach-Which Should it $B e$ ? 22 LAW \& Contemp. Prob. 658, 662 (1957).

${ }^{2}$ Policymaking is a staple of federal agency administration which serves to establish both the short- and long-term goals of administrative discretionary power. See generally H. Friendly, The Federal Administrative Agencies: The Negd for Better Definition of STANDARDS (1962) [hereinafter cited as FriENDLy].

3 DiscretionaRY JUSTICE, supra note 1 , at 55 .

' Id. at 102; FrIENDLY, supra note 2, at 146.

5 The great variety in form which agency policy statements may take is discussed in Discretionary Justice, supra note 1 , at 102 ; K. Davis, Administrative Law Treatise $\$ 5.01$, at 289-90 (1958) [hereinafter cited as Davis TREaTISE]; Davis, An Approach to Legal Control of the Police, 52 Texas L. Rev. 703, 706 (1974).

- A shortcoming of administrators generally is their failure to articulate and publicize such policy determinations as are made. See DisCreTIONARY Justice, supra note 1, at 109-10.

7 See Discretionary Justice, supra note 1, at 54-56.

${ }^{8} \& 553$. Rule making

(a) This section applies, according to the provisions thereof, except to the extent that there is involved-

(1) a military or foreign affairs function of the United States; or

(2) a matter relating to agency management or personnel or to public property, loans, grants, benefits, or contracts.

(b) General notice of proposed rule making shall be published in the Federal Register, unless persons subject thereto are named and either personally served or other. wise have actual notice thereof in accordance with law. The notice shall include- 


\section{development of agency policy.}

Under section 553 of the APA, policy statements which fall within the definition of "rule" provided in section $551^{10}$ must conform to the notice-and-comment requirements of informal rulemaking." Section 553(b)(A) of the APA, however, specifically exempts "general statements of policy" from the notice-and-comment procedure. ${ }^{12}$ Because of the great variety in policy statements, the categories of exempt and nonexempt statements of agency policy are not

(1) a statement of the time, place, and nature of public rule making proceedings;

(2) reference to the legal authority under which the rule is proposed; and

(3) either the terms or substance of the proposed rule or a description of the subjects and issues involved.

Except when notice or hearing is required by statute, this subsection does not apply-

(A) to interpretative rules, general statements of policy, or rules of agency organization, procedure, or practice; or

(B) when the agency for good cause finds (and incorporates the finding and a brief statement of reasons therefor in the rules issued) that notice and public procedure thereon are impracticable, unnecessary, or contrary to the public interest.

(c) After notice required by this section, the agency shall give interested persons an opportunity to participate in the rule making through submission of written data, views, or arguments with or without opportunity for oral presentation. After consideration of the relevant matter presented, the agency shall incorporate in the rules adopted a concise general statement of their basis and purpose. When rules are required by statute to be made on the record after opportunity for an agency hearing, sections 556 and 557 of this title apply instead of this subsection.

(d) The required publication or service of a substantive rule shall be made not less than 30 days before its effective date, except-

(1) a substantive rule which grants or recognizes an exemption or relieves a restriction;

(2) interpretative rules and statements of policy; or

(3) as otherwise provided by the agency for good cause found and published with the rule.

(e) Each agency shall give an interested person the right to petition for the issuance, amendment, or repeal of a rule. 5 U.S.C. $\$ 553$ (1970).

- See, e.g., Attorney General's Comm. on Administrative Procedure, Administrative Procedure in Government Agencies 14-15 (1941) [hereinafter cited as Final Report]; U.S. Dep't of Justice, Attorney General's Manual on the Administrative Procedure Act 14-15 (1947) [hereinafter cited as ATtORnEy General's Manual]; Gellhorn, Public Participation in Administrative Proceedings, 81 Yale L.J. 359, 369 (1972), reprinted in 2 RECOMMENDATIONS and Reports of the Administrative Conference of the United States 376, 386 (1970-72); Verkuil, Review of Informal Rulemaking, 60 VA. L. REv. 185, 189-90 (1974). See also WBEN, Inc. v. United States, 396 F.2d 601 (2d Cir.), cert. denied, 393 U.S. 914 (1968); American Airlines, Inc. v. CAB, 359 F.2d 624 (D.C. Cir. 1966).

10 5 U.S.C. $\S 551(4)(1970)$.

" 5 U.S.C. $\$ 553$ (c) (1970).

125 U.S.C. $\$ 553(\mathrm{~b})$ (A) (1970). Interpretative rules and rules relating to agency organization, procedure, and practice are also exempted by this provision. In addition, statements exempted under this section are exempted from the opportunity to comment requirement imposed by subsection (c). See S. Doc. No. 248, 79th Cong., 2d Sess. 18 (1946) [hereinafter cited as S. Doc. No. 248]. 
clearcut. Instead, policy statements lie on a continuum extending from those which are obviously rules to those which are not. ${ }^{13}$ This comment focuses on distinguishing between policy statements to which section 553 requirements apply and those which are exempt. ${ }^{14}$ The comment proposes an analytic framework which is based on the intended functions of section 553 as expressed by Congress-the protection of private interests ${ }^{15}$ and informed policy making by administrative agencies. ${ }^{16}$ Since, as will be seen below, the definitions of "rule" and "general statements of policy" rarely indicate clearly whether notice-and-comment procedures are required, ${ }^{17}$ there is a large area in the middle of the continuum where the

13 Three examples serve to illustrate the variation in types of policy statements and the difficulty in determining whether a given policy statement is a rule. A policy statement which has been held to be a rule subject to the procedural requirements of section 553 was issued by the Administrator of the Federal Aviation Agency to the Regional Directors of the Agency in 1973. The policy established standards for the use of X-ray equipment in airline baggage inspection and in so doing by implication authorized the use of such $\mathrm{X}$-ray devices by airlines. See Nader v. Butterfield, 373 F. Supp. 1175 (D.D.C. 1974), discussed in text at note 78 infra. On the other hand, in 1961 the Civil Aeronautics Board and the Federal Aviation Agency released a statement of policy to the press which announced the future goal of consolidating reasonably adjacent airports to stem the deterioration in the quality of air service to various areas of the country; this policy was held to be exempt under the "general statements of policy" exemption to section 553. See Airport Comm'n v. CAB, 300 F.2d 185 (4th Cir. 1962), discussed in text at note 96 infra. Finally, somewhere on the continuum between these two policy statements is the "Statement of Policy" issued by the Federal Power Commission in 1973 setting forth the Commission's policy that the national interest would best be served by assigning natural gas curtailment priorities on the basis of "end use" rather than on the basis of prior contractual commitments. The statement further established that the Commission intended to follow this priority schedule unless a particular pipeline company, subject to curtailment, could demonstrate the "extraordinary" circumstance that a different curtailment plan would be more in the public interest. This policy statement was held to be exempt from section 553 requirements in Pacific Gas \& Elec. Co. v. FPC, 506 F.2d 33 (D.C. Cir. 1974). For criticism and discussion of this case, see text and notes at notes 88-91 infra.

1 The analysis presented here is appropriate for use by administrative agencies in determining when to conform to section 553 requirements and by the courts when presented with the question of the validity of a policy pronouncement when section 553 procedures have not been followed.

This comment does not deal with the situation in which an agency refuses to confine its discretionary power through policy making or fails to communicate in any way its position on a policy matter. With respect to this problem, see FrIENDLY, supra note 2, at viii \& 145; DisCRETIONARY JUSTICE, supra note 1 , at 56-57.

is See text and notes at notes 49-51 infra.

16 See text and notes at notes 52-54 infra.

17 The Second Circuit has recently recognized that the issue of whether a "general statement of policy" is to be considered a rule "is enshrouded in considerable smog." Noel v. Chapman, 508 F.2d 1023, 1030 (2d Cir. 1975). In addition, Professor Davis has noted that "under any view an attempt to distinguish a rule from an announcement of policy which is not a rule seems likely to yield a fuzzy product. . . ." Davis Treatise, supra note $5, \S 5.01$, at 290 . Although the area is one in which clear-cut demarcations are not possible, this fact does not lessen the need for analysis of the issue. Administrators and courts must face the decision as to the applicability of section 553 to policy statements on a regular basis. 
applicability of section 553 should be determined largely by the extent to which notice-and-comment would serve the protection and informed policy-making functions. Analysis of this issue, however, must also take into account the competing values and considerations which underlie the exemptions to section 553 procedures. Since Congress has not provided a framework for the implementation of its multi-faceted intent, this comment attempts to systematize the congressional concerns and provide an analytic framework that is sensitive to the competing values articulated by the national legislature.

This comment proposes a three-stage analysis in order to implement a functional approach to the applicability of section 553 procedures to agency policy statements. The first step is to determine whether the protection function alone requires use of section 553 procedures. Private interests can be affected by agency policy in one of three settings: (1) when the agency policy pronouncement produces a substantial impact on affected parties and is binding in that affected parties have no opportunity to challenge the policy before its application to them; (2) when the impact is less than substantial but the policy is binding nonetheless; and (3) when the impact is substantial but the policy is only possibly binding. ${ }^{18}$ In the first permutation alone, section 553 procedures are required by current judicial standards; ${ }^{19}$ only here does the protection function by itself compel informal rulemaking. In the second and third permutations the need for protecting affected parties is somewhat less and does not provide independent justification for requiring section 553 procedures. In these situations, the analysis proceeds to the second stage. The informed policy making function is the key variable at this point; if section 553 procedures will provide useful information not otherwise available to the agency, the policy statement should be considered a rule.

The third stage in the analysis involves the situation in which the protection and informed policy-making functions can be only

18 Section 553 procedures should not be required where the protection function would not be served. The requirements of this section were not intended to be used where the only function to be served is information gathering by the administrative agency. S. Doc. No. 248, supra note 12 , at 20 . Thus, although the protection function alone can serve as the justification for requiring section 553 procedures, the informed policy-making function cannot. This is not an unreasonable position since it could be argued that any agency action would benefit from some additional information on a given issue. This comment is concerned with establishing an analytical framework which provides a technique whereby the interplay of the two functions can be applied to agency policy statements in a manner consistent with congressional intent on the matter.

"See text and notes at notes 69-79 infra. 
insubstantially served by the use of section 553 procedures. In this situation, concerns regarding efficiency and the possibility of driving agency policy making "underground"20 become operative. When these concerns prove to be substantial, rulemaking should not be required.

\section{The Definitional Approach}

\section{A. The Administrative Procedure Act}

The structure of the APA requires agencies, affected parties, and the courts to distinguish between policy statements which are rules and general statements of policy which are not. ${ }^{21}$ Section 551 (4) of the APA defines the term "rule" for purposes of the section 553 notice-and-comment procedures as "the whole or part of any agency statement of general or particular applicability and future effect designed to implement, interpret, or prescribe law or policy or to describe the organization, procedure, or practice requirements of any agency. ...."22 This definition of "rule" explicitly includes policy statements while section $553(\mathrm{~b})(\mathrm{A})$ specifically exempts "general statements of policy" from the requirements of rulemaking. ${ }^{23}$ The Act does not, however, contain guidelines for determining which policy statements are exempt from rulemaking requirements or attempt to reconcile the conflicting references to agency policy statements made in the Act. ${ }^{24}$

20 The phrase "driving policy making underground" refers to the possibility that administrators will, to avoid section 553 procedures, conceal their policies. See Statement of Professor Kenneth C. Davis cited in Bonfield, Some Tentative Thoughts on Public Participation in the Making of Interpretative Rules and General Statements of Policy under the A.P.A., 23 AD. L. REv. 101, 113 (1970) [hereinafter cited as Bonfield Ad. L. Article].

21 A judicial finding that an agency should have complied with section 553 procedures invalidates the rules in question. See, e.g., NLRB v. Wyman-Gordon Co., 394 U.S. 759 (1969); United States v. Finley Coal Co., 493 F.2d 285 (6th Cir.), cert. denied, 419 U.S. 1089 (1974); Wagner Elec. Corp. v. Volpe, 466 F.2d 1013 (3d Cir. 1972); City of New York v. Diamond, 379 F. Supp. 503 (S.D.N.Y. 1974).

225 U.S.C. $\$ 551(4)(1970)$.

${ }^{23} 5$ U.S.C. $\$ 553(\mathrm{~b})(\mathrm{A})(1970)$.

24 The difficulty in distinguishing between various kinds of policy statements is augmented by the variety of terms used in different sections of the APA. Section 552 (the Freedom of Information Act) requires publication in the Federal Register of "substantive rules of general applicability . . . and statements of general policy or interpretations of general applicability. . . ." 5 U.S.C. \& 552(a)(1)(D) (1970). On the other hand, section 552 also provides that "[e]ach agency . . . shall make available for public inspection and copying . . . those statements of policy and interpretations . . . adopted by the agency and . . . not published in the Federal Register." 5 U.S.C. $\$ 552(a)(2)(B)(1970)$.

When a statement of policy or an interpretation adopted by an agency has not been published in the Federal Register, it is presumably because the policy was not one of general applicability. Sofaer, Judicial Control of Informal Discretionary Adjudication and 


\section{B. Nonstatutory Sources of Definition}

1. "General Statements of Policy." The first attempt to define "general statements of policy" was made in the Attorney General's Manual on the Administrative Procedure Act, which described them as "statements issued by an agency to advise the public prospectively of the manner in which the agency proposed to exercise discretionary power." ${ }^{25}$ This definition emphasizes that such statements are future-oriented and do not establish firm and mandatory regulations; they inform the public what the agericy intends to do. ${ }^{26}$ This definition has limitations for determining the breadth of the "general statement of policy" exemption, however, because rules clearly subject to notice-and-comment procedures may possess these characteristics as well. ${ }^{27}$

A "general statement of policy" has also been characterized as nonbinding, whereas a rule is said to establish a "binding norm." ${ }^{28}$ This approach emphasizes that rules are adopted pursuant to a grant of legislative power by Congress ${ }^{29}$ and have the force and effect of law $w^{30}$ whereas general statements of policy lack such force. This

Enforcement, 72 CoLUM. L. REv. 1293, 1334 (1972). Failure to publish the policy or interpretation renders it without force or effect. Gardiner v. Tarr, 341 F. Supp. 422 (D.D.C. 1972). The Gardiner court, without explanation, equated agency policy statements subject to the rulemaking requirements of section 553 with those required to be published in the Federal Register under section 552 .

In addition, section 553 provides that the required publication of a substantive rule must be made at least thirty days before its effective date but exempts "interpretative rules and statements of policy" from the requirement. 5 U.S.C. $\$ 553(\mathrm{~d})(2)$ (1970). The term "substantive rule" seems to refer to rules subject to notice-and-comment procedures. See Lewis-Mota v. Secretary of Labor, 469 F.2d 478, 481 (2d Cir. 1972). It might therefore be argued that the "statements of policy" exempted under section $553(\mathrm{~d})(2)$ are equivalent to "general statements of policy" exempted from the rulemaking requirements under section $553(\mathrm{~b})(\mathrm{A})$. This equivalence is of no aid in defining one or the other, however, since neither the statute nor the case law has defined either term.

${ }^{25}$ Atrorney General's Manual, supra note 9, at $30 \mathrm{n}$.3. The Manual was written shortly after the passage of the APA to explain the Act's purpose and effect to administrative officials.

2s One court has found that an agency was not engaged in rulemaking where its action was not one of approval or prescription. Public Util. Comm'n v. United States, 356 F.2d 236 (9th Cir.), cert. denied, 385 U.S. 816 (1966).

${ }_{27}$ See text and notes at notes 10-14 supra.

${ }^{2 s}$ Parker, The Administrative Procedure Act: A Study in Overestimation, 60 YAlE L.J. 581, 598 (1951) [hereinafter cited as Parker Article]. Parker does not use the term "binding" in relation to opportunity to be heard but rather in relation to the legal effect of the policy-whether it has force of law.

21 DAvis TrEatise, supra note 6, §5.03, at 299.

s0 Atchison, T. \& S.F. Ry. v. Scarlett, 300 U.S. 471 (1937); United States v. Michigan Portland Cement Co., 270 U.S. 521 (1926); see Hearings on S. 1160, S. 1336, S. 1758, and S. 1879 Before the Subcomm. on Administrative Practice and Procedure of the Senate Comm. on the Judiciary, 89th Cong., 1st Sess. 452 (1965) [hereinafter cited as Hearings on S. 1160]. 
perception, however, operates more as a conclusory concept than a method of analysis. Where, for example, an agency has statutory authority to promulgate rules, intends to adopt a rule with binding legal effect, and follows section 553 procedures, the resulting policy pronouncement is undoubtedly a "rule" with force of law. Where, however, the agency's intent with regard to the legal effect of its policy is ambiguous and the agency has not followed rulemaking procedures but has the statutory authority to do so, asking whether the policy has force of law may be much the same as asking whether notice-and-comment procedures are required.

The definitions of "general statements of policy" thus embody three characteristics: they are prospective; they communicate agency intentions; and they are nonbinding. Where the nature of the pronouncement or its binding effect is unclear-in the center of the continuum where policy statements merge into rules ${ }^{31}$ - these definitions are not very useful in determining the applicability of section 553 requirements.

2. Definitions of "Rules." Attempts to define a "rule" encounter many of the same difficulties of imprecision as the efforts to define "general statements of policy." Definitions of rulemaking generally focus on the difference between rulemaking and adjudication and do not attempt to differentiate between rules to which section 553 requirements apply and other categories such as interpretative rules, opinions, releases, rulings, practices, usages, and policies. ${ }^{32}$ Nevertheless, there are some possible bases of distinction that are mildly helpful in defining "rules."

The legislative history of the APA indicates that section 553 requirements were meant to apply only to the making of "substantive rules";"33 however, Congress made no attempt to clarify the term. ${ }^{34}$ A possible source of explanation is the Final Report of the Attorney General's Committee on Administrative Procedures ${ }^{35}$

In discussing interpretative rules Professor Davis contends that the concept of "force of law" fails to take into account the various refinements in the concept; hence, he advocates speaking in terms of "degrees of authoritative effect of rules." This point is equally applicable to policy statements. DAvis TrEATISE, supra note 5, $\$ 5.05$, at 314 .

31 "At some point," Professor Davis observes, "policy statements shade into interpretative rules which in turn shade into legislative rules. Interpretative rules are considered slightly more formal than policy statements, and they usually have a slightly greater degree of binding effect on the agency-a degree that is seldom clear." DisCrETIONARY JUSTICE, supra note 1, at 103. See also Bonfield Ad. L. Article, supra note 20, at 115.

32 See Davis Treatise, supra note $5, \S 5.01$, at 289.

$33 \mathrm{~S}$. Doc. No. 248 , supra note 12 , at 18.

st See id. at 19.

${ }^{35}$ The Final Report served as the primer for congressional deliberations on administra- 
which uses the term "substantive regulation" to describe regulations developed through an agency's rulemaking function which, like statutes, impose penalties upon or withhold benefits from those who disregard their terms. ${ }^{36}$ This view of "rules" was followed by the Attorney General's Manual which defines "substantive rules" as "rules . . . issued by an agency pursuant to statutory authority and which implement the statute, . . . Such rules have the force and effect of law."37

These definitions offer two possible grounds for distinguishing between rules to which section 553 notice-and-comment requirements apply and exempt statements of policy. The first possible distinction is whether the policy was promulgated pursuant to statutory authority and implements the statute-a regulation is most clearly a rule when adopted pursuant to a specific statutory grant of authority. Since a rule may, however, also rest upon an implied or an unclear grant of power, ${ }^{38}$ whether an agency has actually issued a rule or an exempted policy statement cannot necessarily be determined from construction of statutory provisions. This approach will thus yield a fairly clear conclusion only where there is a statutory grant of power for an agency to make rules in a specific situation and the policies promulgated pursuant to that authority are intended to have legal effect.

A second possible distinction based on these definitions rests on the conclusion that "rules" have the force of law whereas "general statements of policy" do not. ${ }^{39}$ This approach, however, also has limited utility; it merely identifies with certainty the legal effect of the two kinds of policy statements at either end of the continuum. In the middle of the continuum, where general policy statements tend to merge into rules, the approach is less useful because it fails to take into account the degree of authoritative effect ${ }^{40}$ and, more importantly, is unable to designate the degree of authoritativeness a statement possesses.

A third definition simply suggests that rulemaking resembles what legislatures do in enacting statutes and defines rulemaking as "legislation on the administrative level." "Although this definition

tive procedure and was the document upon which the APA was largely based.

"Final Report, supra note 9, at 27.

37 AtTorney General's Manual, supra note 9 , at 30 n.3.

38 Davis TrEatise, supra note $5, \S 5.03$, at 299.

32 See text and notes at notes 28.30 supra.

10 See note 30 supra.

"Willapoint Oysters v. Ewing, 174 F.2d 676, 693 (9th Cir.), cert. denied, 338 U.S. 860

(1949). See also Davis Treatise, supra note $5,85.01$, at 288 n.9. 
establishes the general contours of rulemaking, it depends on conformance to rulemaking procedures as the chief indicator of what is a rule. In situations in which an agency does not follow section 553 procedures but parties are nonetheless bound in some way by the pronouncement, it is less helpful.42

Finally, an agency's own characterization of a particular policy pronouncement provides some but hardly a conclusive indication of its nature. The agency may expressly declare that it intends to promulgate a binding regulation or it may claim that it only has set out tentative guidelines for the future. ${ }^{43}$ Nevertheless, the label an agency places on its pronouncement cannot be considered conclusive; rather, it is what the agency does in fact which is the key. ${ }^{44} \mathrm{An}$ agency without rulemaking power may not turn an informal policy into a binding rule by a simple declaration.

In summary, the definitions suggest that a rule, though not a "general statement of policy," has the force of law and therefore tends to have binding effect and that a rule is promulgated pursuant to statutory authority. The definitions further establish that a policy pronouncement is a rule where an agency has statutory authority to make rules, intends that the pronouncement have the force and effect of law, and follows section 553 notice-and-comment procedures. Similarly, the definitions of "general statements of policy" indicate that when an agency decides to issue a nonbinding statement of its future intentions without following section 553 procedures, the agency has promulgated a "general statement of policy." The difficulties arise where an agency has the authority to make rules or general policy statements and does not follow section 553 procedures even though the policy pronouncement has some binding effect and, like a statute, appears to compel specific conduct by the affected parties. In this situation, where general statements of policy merge into rules, the foregoing definitions do not easily categorize the agency pronouncement. Where this is true, it is necessary to turn to the policies underlying section 553 to determine the applicability of its notice-and-comment procedures.

${ }^{42}$ Professor Davis concedes that this analogy to statutes is imperfect and of little use in trying to classify borderline or mixed activities. DAvIS TREATISE, supra note $6, \S 5.01$, at 285 .

${ }^{43}$ Pacific Gas \& Elec. Co. v. FPC, 506 F.2d 33, 39 (D.C. Cir. 1974).

"Lewis-Mota v. Secretary of Labor, 469 F.2d 478, $481-82$ (2d Cir. 1972). See also Columbia Broadcasting Sys., Inc. v. United States, 316 U.S. 407 (1942); Continental Oil Co. v. Burns, 317 F. Supp. 194 (D. Del. 1970); Pharmaceutical Mfrs. Ass'n v. Finch, 307 F. Supp. 858 (D. Del. 1970). 


\section{Rulemaking Functions and Purposes of Exemptions}

\section{A. Rulemaking Functions}

Section 553 of the Administrative Procedure Act requires that an agency, before adopting a rule, must publish notice of the proposed rule and provide interested parties with an opportunity to comment on it. ${ }^{45}$ The legislative history of the APA explains the rationale for these two requirements. ${ }^{46}$ With regard to the notice requirement, the legislative history indicates that public rulemaking procedures are likely to be of little value either to interested persons or the agency unless the subject matter of the proposed rule is announced in advance. ${ }^{47} \mathrm{With}$ regard to the opportunity-tocomment requirement, the legislative history explains that, since an administrative agency is not ordinarily a representative body, "public participation . . . in the rulemaking process is essential in order to permit administrative agencies to inform themselves and to afford safeguards to private interests." 48 Thus, Congress designed section 553 to serve two functions: the education of administrative agencies, which may also be termed encouragement of informed policy making, and the protection of private interests.

1. The Protection Function. Section 553 provides affected parties with an institutional mechanism for defending themselves against the exercise of potentially detrimental discretionary agency power. ${ }^{49}$ The rulemaking notice-and-comment mechanism provides affected parties an opportunity to make the agency aware of possible detrimental effects of its proposed rule before it is enacted and to persuade the agency to change the formulation of a proposed rule in line with the reasons which they offer. Rulemaking is a particularly important protection since Congress is not apt to overrule administrative decisions for reasons of politics or inattentiveness and the courts have a policy of broad deferral to agency discretion. ${ }^{50}$ Thus, opportunity for private parties to provide information to

155 U.S.C. $\S 553(1970)$.

“ S. Doc. No. 248 , supra note 12 , at 18-20.

17 Id. at 18; Final REPORT, supra note 9, at 108.

13. Doc. No. 248, supra note 12, at 19-20; Final Report, supra note 9, at 101-03.

1 Bonfield, Public Participation in Federal Rule Making Relating to Public Property, Loans, Grants, Benefits, or Contracts, 118 U. PA. L. REv. 540, 541 (1970) [hereinafter cited as Bonfield Pa. L. Rev. Article]. See also K. Davis, Administrative Law Text 156 (3d ed. 1972); Hamilton, Procedures for the Adoption of Rules of General Applicability: The Need for Procedural Innovations in Administrative Rulemaking, 60 CALIF. L. REv. 1276, 1313-14 (1972), reprinted in 2 RECOMMENDATIONS AND REPORTS OF THE ADMINISTRATIVE CONFERENCE OF THE UNITEd States 834, 871-72 (1970-72) [hereinafter cited as Hamilton Article].

so Bonfield Pa. L. Rev. Article, supra note 49, at 541-42. 
agencies operates as a significant protection against arbitrary and ill-considered rules. ${ }^{51}$

2. Informed Policy-Making Function. An agency's knowledge and expertise is rarely sufficient to provide all the needed data upon which rulemaking decisions should be based, and interested parties can often provide much of the specific information needed for informed policy making. Notice-and-comment procedures also aid the agencies in determining whether and what kinds of rules should be formulated" and open up "the process of agency policy innovation to a broad range of criticism, advice and data," ing to the sound and fair operation of government. ${ }^{54}$ Thus, the informed policy-making function consists of two elements: to assure that individual agency decisions are made with as much information as possible and, in line with broader systemic needs, to contribute to the process of informed and rational long-term policy development.

Although the informal rulemaking requirements serve two very important functions-the protection of affected parties and informed policy making - these functions must be viewed in light of the congressional reasons for exempting certain agency pronouncements from section 553 requirements. It is to these reasons that this analysis now turns.

\section{B. Legislative Reasons for the Exemptions}

It has been estimated that by reason of the exemptions to sec-

31 Hamilton Article, supra note 49,60 CALIF. L. Rev. at 1314, reprinted in 2 Recommendations and Reports of the Administrative Conference of the United States at 872. Professor Hamilton suggests that there are problems with notice-and-comment rulemaking as a protective device for private interests: "A person adversely affected in some serious way by a proposed rule may find little solace in the opportunity to submit a written comment. He has no way of knowing whether it will be read by the person with the ultimate power of decision, or indeed, whether it will be read at all. Further, even if his views are considered by the proper persons, he may feel that he should be entitled to a greater opportunity to participate in the rulemaking process than the mere opportunity to file written comment." Id. The contrary view, expressed often by agency personnel, is that agencies are careful, fair, and thorough in formulating policy and therefore more formal procedures are unnecessary and tend to obstruct the prompt implementation of programs. Id. This comment is not concerned with the sufficiency of section 553 requirements in fulfilling the functions Congress intended for them; rather, the comment accepts the legislative decision to fulfill these functions through notice-and-comment procedures and seeks to determine when the procedures should be applied to policy statements.

${ }_{22}$ Elman, Rulemaking Procedures in the FTC's Enforcement of the Merger Law, 78 HaRv. L. REv. 385, 385-86 (1964).

${ }^{33}$ National Petroleum Refiners Ass'n v. FTC, 482 F.2d 672, 683 (D.C. Cir. 1973).

${ }^{54}$ Bonfield Pa. L. Rev. Article, supra note 49, at 540-41. 
tion 553 perhaps sixty per cent or more of all federal rulemaking is done without public participation..$^{55}$ The magnitude of this figure and recognition of the role of rulemaking in confining administrative discretion warrant a close evaluation of the congressional reasons for exempting interpretative rules, rules of organization and procedure, and general statements of policy from the requirements of section 553 .

The legislative history of the APA indicates that there were three reasons ${ }^{56}$ for the exemptions listed in section 553(b)(A). First, Congress believed that agencies should be encouraged to develop rules of the types that had been exempted and Congress feared that the procedural burdens of section 553 might discourage agencies from making these rules. Second, because the exempt rules vary so greatly in their content and the occasion for their issuance, Congress deemed it appropriate to grant the agencies discretion to choose whether to undertake notice-and-comment procedures. Third, Congress reasoned that section $553(\mathrm{e})$ of the Act, which provides interested parties with the right to petition for reconsideration of such rules, ${ }^{57}$ was an adequate safeguard against ill-considered exempt pronouncements.

1. Encouragement for the Making of Exempt Rules. In stressing this reason, Congress implicitly recognized that the protection and information-gathering functions are not served sufficiently in the cases of certain types of policy statements to warrant imposing notice-and-comment procedures on the agencies. Administrators may perceive compliance with these procedures as too burdensome and conceal their policies from the public; nothing in the APA prevents an agency from following an unstated, unpublished policy. ${ }^{58}$ Congress therefore reasoned that agencies would be more likely to

${ }_{35}$ K. Davis, Administrative Law: Cases-Text-Problems 280 (5th ed. 1973). This figure apparently includes not only the interpretative rule, general statements of policy, and agency procedure and organization exemptions but also the other exemptions listed in section 553. See the text of 5 U.S.C. $\$ 553$ at note 8 supra.

ss S. Doc. No. 248, supra note 12, at 18. See also Hutton, Public Information and Rule Making Provisions of the Administrative Procedure Act of 1946, 33 TEMP. L.Q. 58 (1959).

575 U.S.C. $\$ 553(\mathrm{e})(1970)$.

s8 Parker Article, supra note 28, at 598. It is true, however, that some courts have begun to require agencies to make rules where their discretionary power is viewed as too unrestricted. In United States v. Bryant, 439 F.2d 642 (D.C. Cir. 1971), for instance, the court required the Government to show that it "promulgated, enforced, and attempted in good faith to follow" procedures designed to preserve evidence gathered during the course of criminal investigation. Id. at 650 . Other decisions have required agencies to give findings and reasons for their decisions. E.g., Dunlop v. Bachowski, 95 S. Ct. 1851 (1975); Environmental Defense Fund v. Ruckelshaus, 439 F.2d 584 (D.C. Cir. 1971). 
make and publicize certain rules if relieved of section 553 obligations. ${ }^{59}$

An additional danger of increased procedural requirements is that some agencies may follow rulemaking procedures where they serve no purpose, thereby increasing their workloads and generating substantial delays in the performance of their general administrative duties. This efficiency concern is a substantial one because agencies, in the course of their routine activities, are continuously taking policy positions on a wide range of matters. ${ }^{60}$ Where the functions of protection and informed policy making can be served, Congress considered administrative delays and the possibility of driving policy making underground by imposing the procedural requirements of section 553 to be risks worth taking. Where such functions are less well served, as Congress deemed was the case with the pronouncements exempted under section $553(\mathrm{~b})(\mathrm{A})$, the risks of excessive rulemaking and the stifling of policy making were deemed less reasonable. Congress did not provide, however, a formula for relating its concern for efficiency to the needs for protection of affected parties and informed policy making.

2. Difficulty in Distinguishing Among the Variety of Agency Pronouncements by Statute. The second reason implicitly given in the legislative history for the exemptions is the difficulty of devising a statutory technique to distinguish policy statements within the exemption from those which are not. In deciding to leave the matter of public participation to the discretion of the agencies, Congress emphasized that where such participation would be helpful to the agencies or to the public, it should be sought. ${ }^{61}$ In so doing, Congress further emphasized that the dual functions of the section 553 noticeand-comment procedure should be the major determinant regarding its applicability. Congress did not, however, fit this reliance on agency discretion into the matrix of other considerations.

3. Right to Petition. The third reason for the exemptions is the availability of the right to petition for the "issuance, amendment, or repeal of a rule" ${ }^{62}$ under section 553(e) of the APA. Yet this right is a poor substitute for notice and comment when those procedures would serve the protection and informed policy-making functions. Although affected parties may have notice of the adopted exempt

\footnotetext{
s. Doc. No. 248, supra note 12, at 18.

${ }^{6}$ Bonfield Ad. L. Article, supra note 20, at 113.

61 S. Doc. No. 248, supra note 12 , at 200.

${ }^{82} 5$ U.S.C. $\$ 553(\mathrm{e})(1970)$.
} 
policy statement through its publication in the Federal Register, ${ }^{63}$ the notice is insufficient because it comes after the rule has been promulgated when the agency is likely to have a vested interest in retaining it unamended. In addition, the denial of a section 553(e) petition may not be subject to judicial review. ${ }^{64}$ Thus, the right to petition provides only a formal opportunity to bring a disagreement with an exempt general statement of policy to the attention of the agency, contributing little more to the protection of private interests. The limitations of the petition procedure are especially acute when the pronouncement has some binding effect on the parties.

\section{A Functional Approach to Determining When Rulemaking Is Necessary in Policy Formulation}

Because the scope of the "general statements of policy" exemption has only recently become a source of controversy, ${ }^{65}$ a systematic determination of its boundaries has not yet been developed. This and other exemptions to section 553 have at times been broadly construed by the courts. ${ }^{66}$ Yet the congressional intention that agen-

see note 24 supra.

“ Attorney General's Manual, supra note 9, at 39; Pacific Gas \& Elec. Co. v. FPC, 506 F.2d 33, 48 (D.C. Cir. 1974). But see National Resources Defense Council, Inc. v. SEC, 389 F. Supp. 689, 702 (D.D.C. 1974). There, the plaintiff had petitioned under section 553(e) for review of existing corporate disclosure regulations and the agency had denied the petition without comment. Since according to the statute the agency shall "[e]xcept in affirming a prior denial or when the denial is self-explanatory, . . . [give] a brief statement of the reasons for denial," the court required the agency to state its grounds for denial, and specifically referred the Commission to an amicus curiae brief supporting the changes requested by the plaintiff. Requiring reasons for denial of a petition compels more careful agency consideration of its grounds, and may serve in the future as a technique for obtaining substantive judicial review. Yet section $553(\mathrm{e})$ is neither a protective nor data-gathering mechanism; it is only a limited check on regulatory decision making.

ss Three cases decided in 1974 dealt with the subject: Pickus v. United States Bd. of Parole, 507 F.2d 1107 (D.C. Cir. 1974); Pacific Gas \& Elec. Co. v. FPC, 506 F.2d 33 (D.C. Cir. 1974); and Nader v. Butterfield, 373 F. Supp. 1175 (D.D.C. 1974). Earlier, three cases touched on related issues: Airport Comm'n v. CAB, 300 F.2d 185 (4th Cir. 1962) (publication under original section 3(a) of APA); Brownell v. Schering Corp., 129 F. Supp. 879 (D.N.J. 1955), aff'd, 228 F.2d 624 (3d Cir.), cert. denied, 351 U.S. 954 (1956); and the Supreme Court examined judicial review of policy statements in the landmark case of Columbia Broadcasting Sys., Inc. v. United States, 316 U.S. 407 (1942).

"See, e.g., Continental Oil Co. v. Burns, 317 F. Supp. 194 (D. Del. 1970), where, despite its recognition that "[ $t]$ he basic policy of section 553 at least requires that when a proposed regulation of general applicability has a substantial impact on the regulated industry . . . notice and opportunity for comment should first be provided," the court held that the Federal Reserve Board's pronouncement construing the Truth in Lending Act was an interpretative rule to which section 553 procedures did not apply. In Pacific Gas \& Elec. Co. v. FPC, 506 F.2d 33 (D.C. Cir. 1974), the Commission's representation of the effect of its policy statement was accepted by the court with little attention to the policy's practical effect on the parties. See text and notes at notes 88-91 infra. 
cies follow notice-and-comment procedures where the protection and informed policy-making functions can be served ${ }^{67}$ suggests that a narrower interpretation of the exemptions is appropriate. Although this congressional intent should not be undermined by an expansive interpretation of the section 553 exemptions, the courts have taken only the first steps in the direction of narrowing the scope of the exemptions. Courts have frequently looked to the protection function in determining whether the procedural safeguards of section 553 are required, but they have not as yet carried the functional analysis to the point where both of the section 553 functions are considered in their various permutations. ${ }^{68}$ The following analysis suggests the relative weight to be given to these functions-and the countervailing considerations of administrative efficiency and encouragement of open policy formulation-in determining whether notice-and-comment procedures are required.

\section{A. The Protection Function}

The first stage in the proposed analysis focuses on the protection function of section 553 which has two elements: first, whether the policy statement produces a substantial impact on the rights and obligations of affected parties; and second, whether this policy statement is binding in that the parties have no opportunity to comment before the policy becomes effective.

1. Substantial Impact on the Rights and Obligations of Affected Parties. Emphasis on this aspect of the protection function represents the merger of the two principal judicial approaches to determining when an agency policy pronouncement is a rule. The first approach is referred to as the "substantial impact" test. In Pharmaceutical Manufacturers Association v. Finch $(P M A)^{69}$ the district court formulated a standard for determining when an agency statement is to be considered a rule under section 553:

[W] $]$ hen a proposed regulation of general applicability has a substantial impact on the regulated industry, or an important

67 See text and notes at notes $45-54$ supra.

is See text and notes at notes 18-20 supra.

69 307 F. Supp. 858 (D. Del. 1970). In PMA the Food and Drug Administration vainly argued that section 553 procedures were not required because the regulations issued by the agency detailing new standards of evidence necessary to demonstrate the effectiveness of drug products were merely procedural and interpretative. The court's analysis is equally applicable to the general statements of policy exemption. 
class of the members or the products of that industry, notice and opportunity for comment should first be provided. ${ }^{70}$

The court found that Federal Drug Administration regulations which placed in jeopardy of summary removal from druggists' shelves over 2000 drug products first marketed between 1938 and 1962 with FDA approval, produced a "substantial impact," an impact compounded by the reliance of drug manufacturers on the earlier FDA standards. Although the court was able to conclude that a "substantial impact" was present, it did not explain when an impact could be considered substantial. ${ }^{71}$

While no test has been devised to determine whether an impact is "substantial," the Third Circuit gave greater specificity to the concept of "substantial impact" in Texaco v. FPC.72 After stressing that notice and comment should be followed "before establishing rules ... which have a substantial impact on those regulated," 73 the court found a pronouncement changing the method of computing certain rebates to fall outside the "general statements of policy" exemption and therefore within the area in which section 553 notice and comment was required. The court asserted that a "general statement of policy' is one that does not impose any rights or obligations" 74 on affected parties, thereby implicitly equating an alteration of rights or obligations with substantial impact. This notion, although often couched in different language, seems to underlie the other decisions requiring rulemaking procedures upon a finding of substantial impact. ${ }^{75}$

70 307 F. Supp. at 863.

"The standard developed in the PMA case has also been applied in such cases as Akron, C. \& Y.R.R. v. United States, 370 F. Supp. 1231 (D. Md. 1974), and Continental Oil Co. v. Burns, 317 F. Supp. 194 (D. Del. 1970), in determining the scope of the exemptions listed in section 553(b)(A).

72412 F.2d 740 ( $3 \mathrm{~d}$ Cir. 1969). In the court below the Commission had sought to rely on the "good cause" exemption to section 553, 5 U.S.C. \& 553(b)(B), contending that the insignificance of the subject matter rendered notice and comments unnecessary. On appeal the Commission sought to rely additionally on the "general statements of policy" exemption, an argument which the court considered while reminding the agency that it could not introduce a new theory on appeal. 412 F.2d at 744 n.9.

73412 F.2d at 744 .

74 Id.

${ }^{75}$ E.g., Lewis-Mota v. Secretary of Labor, 469 F.2d 478 (2d Cir. 1972); PMA v. Finch, 307 F. Supp. 858 (D. Del. 1970). Although the regulations in Pickus v. United States Bd. of Parole did not require inmates to "change their behavior to conform," they were found to "substantially affect" the rights of potential parolees because of the "considerable impact" of the regulations on parole determinations. 507 F.2d 1107, 1114 (D.C. Cir. 1974). Similarly, the procedures challenged in Nader v. Butterfield, 373 F. Supp. 1175 (D.D.C. 1974), changed the rights of the consumer only insofar as they left him powerless to avoid being exposed to 
The courts' decisions in PMA and Texaco stress the effect on the parties as the major determinant of whether an agency pronouncement is a rule. Both courts stated that notice-and-comment procedures were required where a regulation could produce substantial impact on the rights or obligations of the parties. Although neither court discussed whether the regulations were binding on the affected parties, each court implicitly assumed that they were. These cases thus fall within the first permutation of the protection function, where the protection function alone compels rulemaking. Other courts, however, have given more explicit recognition to the second aspect of the protection function.

2. Binding Effect: Whether There is Opportunity to Comment. Where an agency pronouncement has a substantial impact on the rights and obligations of affected parties which is binding, in that affected parties have no opportunity to challenge the policy statement before its application to them, the agency should engage in section 553 rulemaking. ${ }^{76}$ The decision in Seaboard World Airlines, Inc. v. Gronouski ir illustrates a court's explicit concern with both elements of the protection function. The court found that the agency's policy had a substantial impact because it deprived Seaboard of almost all of its mail revenue, a major proportion of its business, even though the company was afforded no opportunity to present its views to the Post Office. The court stressed that the new policy had the "force of prescribing a course of conduct which is binding on the defendant's agents and with which the plaintiff is required to comply."'78

An even greater concern for the opportunity-to-be-heard dimension of the protection function was exhibited in Nader $v$. Butterfield, ${ }^{79}$ the facts of which illustrate how statements of policy may be binding on affected parties. At issue was a Federal Aviation Administration memorandum circulated to its regional offices pre-

potentially harmful X-rays. But cf. Continental Oil Co. v. Burns, 317 F. Supp. 194, 197 (D. Del. 1970).

${ }^{76}$ See Fuchs, Procedure in Administrative Rulemaking, 52 HaRv. L. REv. 259, 271-72 (1938).

7230 F. Supp. 44 (D.D.C. 1964). The case involved a U.S. Post Office regulation that changed a policy from one which permitted mail to accumulate and go out on the first allcargo flight available to one which required all mail to be routed by the most expeditious air service. Seaboard employed turbine equipment for its cargo flights which could not compete with the speed of jets and the frequency of the scheduled airlines which employed them.

${ }^{78}$ Id. at 46 . The court also rejected the argument that because the policy was directed at agency personnel and not at the public, it fell under the personnel or procedure exemption to section 533. Id.

773 F. Supp. 1175 (D.D.C. 1974). 
scribing criteria and standards for use of X-ray equipment by lines for "carry-on" baggage inspection. The FAA contended that the memorandum merely provided policy guidance to field employees and that it did not impose a mandatory regulation. The court's decision to require rulemaking was not based on whether the procedures were mandatory but on the fact that X-ray equipment would be put into operation before affected parties, such as airline employees or passengers, had the opportunity to present information regarding health hazards known to exist in the use of X-ray equipment.

In Seaboard and Nader the policy statements produced substantial binding impacts on the parties-one economic, the other involving health and safety. The parties had no opportunity to submit evidence on the appropriateness of contrary agency action before they were substantially affected by the policy. These cases too, like PMA and Texaco, fall within the first permutation of the protection function, where the protection function alone is sufficient to compel notice-and-comment rulemaking.

\section{B. Informed Policy Making}

1. Situations in Which the Informed Policy-Making Function Should Be Relevant to the Applicability of Rulemaking Procedures. The process of policy development by administrative agencies can be usefully served by the incorporation of additional information and divergent views. Where the protection function of section 553 does not in itself present a compelling case for the use of notice-andcomment procedures, the applicability of these procedures should depend upon the extent to which the information collected through the section 553 process will contribute to the agency decisionmaking process.$^{80}$ The informed policy-making function should serve as the key variable in determining whether section 553 procedures should be used in situations falling within the second and third permutations of the protection function: (1) where the agency's policy statement is binding on the parties but the impact is less than substantial; and (2) where the impact is substantial but only possibly binding on the parties. The former situation is illustrated by the case of Pickus $v$. United States Board of Parole ${ }^{81}$ while

so The informed policy-making function demands that the agency base its policy decisions on the facts as they are, not as the agency believes them to be. See Cramton, Administrative Procedure Reform: The Effects of S. 1663 on the Conduct of Federal Rate Proceedings, 16 AD. L. REv. 108, 111-12 (1964).

81507 F.2d 1107 (D.C. Cir. 1974). 
an example of the latter can be found in National Motor Freight Traffic Association v. United States. ${ }^{82}$

In Pickus the District of Columbia Circuit was asked to evaluate guidelines announced by the Board of Parole which specified factors to be considered in determining the eligibility of federal prisoners for parole. In rejecting the contention that the pronouncements of the Board of Parole were exempt from notice-andcomment procedures under section $553(\mathrm{~b})(\mathrm{A})$, the court stated, "If the regulations regarding parole hearings are likely to produce parole decisions different from those which alternatives would be likely to produce, then the exemption should not apply." 83 The impact found by the court was not substantial in the sense that the guidelines and regulations would definitely produce a significant or decisive effect on the parole decision. Rather, the court was willing to require section 553 procedures where such regulations were "likely to produce" different parole decisions. The court's interest in protecting affected parties from a "likely" different result was buttressed by its concern for performance of the informed policymaking function. The court stressed the interaction of the twin functions of section 553 in determining that notice-and-comment procedures were necessary:

The outer boundary of the general policy exemption derives from Congressional purpose in enacting Section [553]-that the interested public should have an opportunity to participate, and the agency should be fully informed, before rules having substantial impact are promulgated..$^{84}$

82268 F. Supp 90 (D.D.C. 1967), aff'd mem., 393 U.S. 18 (1968).

${ }^{83} 507$ F.2d at 1114.

8t Id. at 1112. The court failed to note that the Board of Parole does not have legislatively authorized rulemaking power. See 18 U.S.C. $\$ 4201$ (1970). This omission does not, however, affect the validity of the court's approach. Courts should not hold that agency pronouncements are not subject to section 553 solely because the agency lacks rulemaking authority. But see Davis TEXT, supra note $55, \S 5.06$, at 137: the rationale for this approach is that the courts are free to engage in plenary judicial review of an interpretative rule, policy statement, or procedure where section 553 procedures have not been followed. The difficulty with this view is that the court may treat the agency pronouncement as an interpretative rule, as the Government argued in Pickus, and give it binding effect based on deference to agency expertise in the particular area. See Skidmore v. Swift \& Co., 323 U.S. 134, 140 (1944). Thus, the availability of plenary judicial review of policy statements may very well be an incomplete protection. If the approach based solely on the existence of rulemaking authority is accepted, an agency pronouncement will be allowed to operate against parties who had neither an opportunity to comment on it before being affected nor an assurance that the protection of judicial review would be available. If a court determines that the protection of interested parties requires that an agency pronouncement conform to section 553 procedures, as the Pickus court did, but the agency has not been given rulemaking authority by Congress, the 
Thus, where the protection function plays a significant, but noncompelling, role because the binding policy only possibly produces a substantial impact, the goal of informed policy making can tip the balance to require notice and comment. A similar interplay between the functions is appropriate where the impact of a policy statement on the parties is substantial but the statement is only possibly binding.

In National Motor Freight the court was asked to invalidate an Interstate Commerce Commission statement detailing the procedures to be followed by shippers seeking reparations for past unreasonable motor freight charges on the ground the Commission had not followed section 553's notice-and-comment requirements. ${ }^{85}$ The Commission contended that notice and comment was not required; it argued that since the new procedures applied only where the formerly effective rate had been changed, the plaintiffs had an adequate opportunity to challenge the procedures by protesting the filing of a new rate. In rejecting this argument the court noted that when a new and lower rate is filed, it may fall in an area of reasonableness that included the old rate as well, so that the Commission's subsequent approval of the new rate would not necessarily include a determination that the old rate was illegal. Hence, the plaintiffs might never have the issue of the procedure's validity reviewed by the Commission in a later proceeding. Thus, the court concluded that a section 553 exemption did not apply because the plaintiffs might be denied an opportunity to be heard on a procedure which produced a substantial impact on their businesses. ${ }^{86}$ The possibility of the lack of an opportunity to comment was sufficient to require notice-and-comment procedures:

[T] hat very quality of importance [the opportunity to comment] - to the industry and to the public-is what lies at the

appropriate response for a court is not to give the pronouncement effect as a "general statement of policy" but to require that the policy statement be reformulated to have a less substantial impact on the parties.

ss Although the procedure exemption to section 553 was the basis for appeal, the court also found that the policy was not exempt as a "general statement of policy." In addition, subsequent courts have applied the reasoning of the National Motor Freight court to their reviews of policy statements. See Pickus v. United States Bd. of Parole, 507 F.2d 1107, 1112 (D.C. Cir. 1974).

st The National Motor Freight court initially discussed the possibility that the plaintiffs would have no opportunity to contest the finding that the rate was too high in the context of standing to sue. Nevertheless, the court's reference to this discussion in its analysis of the section 553 issue appears to indicate that the inadequate opportunity for the parties to comment was the basis of the court's determination that rulemaking procedures were necessary. 268 F. Supp. at 96. 
base of Section [553] of the APA and which informs the Congressional purpose in that law to expose proposed agency action by general rule to the test of prior examination and comment by the affected parties. ${ }^{87}$

The court implicitly recognized the interplay between the protection and the informed policy-making functions of section 553 where an agency pronouncement produces a substantial impact on affected parties with a possibly binding effect.

The courts do not, however, always consider the interplay between the dual functions of section 553 as they should. In Pacific Gas \& Electric Co. v. FPC ${ }^{88}$ the District of Columbia Circuit ignored aspects of both the protection and informed policy-making functions which, if recognized, would seem to have called for invalidating the policy in question because it had been promulgated without notice-and-comment. At issue was a Federal Power Commission policy statement requiring natural gas pipeline companies to file curtailment plans for periods of peak demand for natural gas. The statement indicated that FPC approval of the plans would be contingent on use of an "end use" basis for the schedules, and thus left little doubt that the policy would have a substantial impact on the distributors of gas and their customers. Ignoring that impact, the court held that the policy statement did not provide an inflexible, binding rule but merely provided advance notice of a general policy which could be challenged by affected parties in the adjudicatory hearings that would be held regarding each proposed schedule. The later opportunity to challenge the policy was found sufficient to protect the parties and inform the agency. However, the FPC's statement actually revealed that this opportunity might be illusory: "Barring extraordinary circumstances, our review . . . convinces us that the priorities-of-delivery . . . should be applied to all jurisdictional pipeline companies during periods of curtailment." 89 Thus, the later opportunity to comment on the appropriateness of the policy was merely formal, and the strong presumption in favor of the agency's position made the policy effectively binding.

Where, as in the Pacific Gas case, a policy will produce a substantial impact on affected parties without offering the parties an effective opportunity for advance comment, the court should consider whether requiring notice and comment would serve the func-

\footnotetext{
${ }^{87}$ Id. at 96.

s8 506 F.2d 33 (D.C. Cir. 1974).

so Id. at 50 , citing 49 F.P.C. at 584.
} 
tion of informed policy making. The Pacific Gas court did not consider the need to inform the FPC and to make outside points of view available to the agency on this issue at a time when the allocation of fuel resources was a major national issue. The agency might have found such views useful in the development of this important policy; indeed, the FPC might have chosen a different formulation of the policy if it had had the benefit of this additional information..$^{90}$ Given the clearly expressed intent of Congress regarding the functions of section 553, it is not unreasonable to argue that "in marginal cases an agency should resolve the doubt in favor of giving the public and industry members an opportunity to comment on a proposed rule before it is finally adopted." "91

2. Factors Suggesting When the Informed Policy-Making Function Can Be Served. The significance of the informed policymaking function to rational agency policy development, and Congress's concern that the function be considered, compel full consideration of its role where the protection function alone does not compel use of rulemaking procedures. Of the countless situations in which section 553 rulemaking can gether information crucial to intelligent policy formulation, four categories of situations stand out in which the section 553 procedures are likely to provide the agency with helpful or needed information that it would not be likely otherwise to obtain.

a. Limited Agency Expertise. ${ }^{92}$ Where the agency is not technically proficient in the field in which policy is being formulated, the opportunity-for-comment procedure is an appropriate method of overcoming this deficiency.$^{93}$ In Nader $v$. Butterfield, ${ }^{94}$ for instance, the FAA had promulgated standards for the use of X-ray equipment for baggage inspection. Since the FAA was unfamiliar with the dangers of X-ray equipment and lacked the expertise to evaluate these dangers, outside information should have been sought to provide a basis for reasoned decision making.

b. Limited Data on the Impact of the Policy. In Lewis-Mota v. Secretary of Labor ${ }^{95}$ the Secretary had, by suspension of a precer-

30 See Pickus v. United States Bd. of Parole, 507 F.2d 1107 (D.C. Cir. 1974).

" Devcon Corp., 20 Ad. L. Dec. 2d 592, 597 (FTC 1966) (Comm'r Elman, dissenting).

12 See Fuchs, supra note 76, at 270-71.

${ }^{23}$ Of course there may be some situations involving highly specialized expertise in which consultation by the agency with a few industry experts will provide all the information the agency is likely to need.

373 F. Supp. 1175 (D.D.C. 1974).

s 469 F.2d 478 (2d Cir. 1972). 
tification list, made it necessary for aliens with occupations on the list to prove that they had a specific job offer in order to enter the United States. The court concluded that the Secretary's action detrimentally affected the ability of employers to fill vacancies in the occupations no longer precertified, leaving those employers without recourse from immediate injury. Adherence to section 553 procedures would have enabled the Department of Labor to become better informed on the impact of the proposed action on the affected employers.

c. Insufficient Practical Experience. In Airport Commission v. $C A B^{96}$ the administrative action at issue was the Civil Aeronautic Board's decision to order the consolidation of two North Carolina airports. According to the court, the CAB's order was based on the 600 -page record of a hearing it had held on the proposed consolidation. The CAB's decision to receive the comments of outside parties made crucial information available to the agency on the feasibility of the consolidation, the needs of passengers and shippers in the Piedmont area of North Carolina, and the ability of airlines to improve services to the region as a result. The utility of outside information on these kinds of practical questions should determine whether section 553 requirements are justified by the informed policy-making function. ${ }^{97}$

d. The Need for Attention to Broader Policy Development. Regulatory agencies generally neglect broad policy development ${ }^{98}$ despite the suitability of section 553 procedures for this purpose.99 A prime example of this is the FPC's failure to recognize the value of notice and comments in development of long-term policy in the Pacific Gas \& Electric ${ }^{100}$ case. Agencies should devote greater attention not only to developing an internally consistent body of policy, but also to formulating policies which are integrated with those of other agencies. When rulemaking procedures could aid in that development, they should be employed.

The informed policy-making function of section 553 is meant to encourage the interchange of ideas between the government and its citizens, thereby providing a broader base for intelligent decision

98 300 F.2d 185 (4th Cir. 1962).

"The court in Airport Commission held that the CAB's order was based on substantial evidence and that the order was the product of neither rulemaking nor adjudication under the APA. Id. at 187-88.

88 J. Landis, Report on Regulatory Agencies to the President-Elect 22 (1960).

"See text and note at note 9 supra.

${ }_{100}$ See text and note at note 88 supra. 
making. ${ }^{101}$ Where the need for protection of affected parties is not strong enough to demand conformity to section 553 , but is nevertheless present in some significant degree, and useful information can be provided to the agency through notice-and-comment procedures, section 553 should apply to the agency pronouncement.

3. Administrative Efficiency and the Need for Nonbinding Policy Making. Where the protection function does not by itself compel compliance with section 553's protective requirements, and the informed policy-making function can be only marginally served, the determinants of whether notice-and-comment procedures are required should be the extent to which such a requirement will impede administrative efficiency and the issuance of policy statements. The rationale of the efficiency dimension stems from the notion that, although the exercise of agency discretion should in general be structured by rulemaking, this structuring can be accomplished as well in some instances by the use of exempt "general statements of policy" without sacrificing fairness or accuracy. Yet society's interest in assuring public participation in the rulemaking process, and in the development of informed policies, is sufficiently important that exemptions from notice-and-comment procedures should be countenanced only to the extent they are absolutely necessary to preserve other values of equal or greater importance. ${ }^{102}$ Although efficiency in government is assuredly one of these values, agencies must be careful not to overemphasize this consideration since the complaint that increased cost, larger workloads, and general delay result from the application of section 553 requirements to policy statements can also be made with respect to rules clearly subject to section 553 provisions. Similarly, the concern for not driving policy making underground because administrators perceive section 553 procedures as too burdensome must always be weighted in light of the strong congressional objectives of protecting affected parties and encouraging informed policy making. Thus, the two functions of section 553 should yield to the efficiency dimension only where the functions will be insubstantially served by rulemaking procedures and the efficiency dimension will be substantially served.

There are at least three factors which should be considered in

101 See Kelly v. United States Dep't of Interior, 339 F. Supp. 1095, 1102 (E.D. Cal. 1972).

${ }_{102}$ See Bonfield Pa. L. Rev. Article, supra note 49, at 545; Bonfield Ad. L. Article, supra note 20 , at 106 . This statement is, of course, also consistent with the strongly expressed congressional desire to serve these two functions. See text and notes at notes 55-57 supra. 
determining the weight to be given to the efficiency dimension: the frequency of agency promulgations of the same kinds of policies, the value of the comments likely to be elicited and the amount of comment likely to result from engaging in section 553 notice and comment.

a. Frequency in Issuance of Similar Policies. Where an agency frequently issues policy statements that are similar in kind and effect, requiring notice and comment before issuing each of those statements may cause an administrator to refrain from articulating the statements, thereby injuring instead of benefiting the public. If this is the case, rulemaking should not be required in situations where the functions of protection and informed policy making will be only minimally served.

Hearst Radio v. FCC ${ }^{103}$ involved a Federal Communications Commission policy statement entitled "Public Service Responsibility of Broadcast Licensees." The court held that the publication of the statement by the FCC did not constitute "agency action" and therefore was not subject to judicial review. Had the policies contained in the statement been promulgated separately in accordance with section 553 procedures, the workload on the FCC would have been great, and neither the protection of licensees nor the collection of relevant data would have been advanced thereby. Although the Hearst case does not specifically illustrate the likelihood that an administrator will go underground with policy making, it does indicate that the likelihood of agency promulgation of similar policies is a factor to be considered in evaluating the need for section 553 rulemaking.

b. Value of Outside Comment. Where, for example, the Federal Aviation Administration is considering a policy concerning the functioning of a highly technical piece of airplane equipment, solicitation of outside comments may produce little or no information that will add to the expertise of the FAA or to information already gleaned from informal contacts with airline experts. Therefore, where the solicitation of comment is likely to produce little information of additional value, and observation of notice-and-comment procedures will produce an inefficient use of an agency's time and resources, rulemaking should not be required.

c. Amount of Comment Likely to Result. An agency may receive either so much comment on a particular subject that it will 
not be efficient for it to spend time examining submissions or so little comment that the procedural formalities will not be worthwhile. The assessment of this factor is likely to be speculative; hence, only limited weight should be accorded it in the balancing of the efficiency dimension against the protection and informed policy-making functions. Nevertheless, the need for efficient and economical government should not be overlooked and procedures should not be required where unnecessary.

This concern for efficiency and for the continued use of nonbinding general policy statements is meant to operate as a safety valve. Its judicious use will prevent the courts and agencies from using the functional approach to require rulemaking in the cases where the functions underlying section 553's notice-and-comment procedures will not be thereby served.

\section{CONCLUSION}

The analytic framework proposed in this comment provides an approach for determining the appropriateness of rulemaking in the promulgation of agency policy statements which is consistent with the intent of Congress as expressed in the legislative history of the Administrative Procedure Act. The approach is based on the various permutations of the functions of notice-and-comment procedures and the competing functions to be served by the exemptions to section 553. The central message of this comment is that courts and agencies, if they are to give full expression to the intent of Congress, should consider each permutation of the functions in determining whether the agency pronouncement is a rule or an exempt policy statement. If such a complete, systematic approach is followed, clearer standards will emerge and the "considerable smog"104 surrounding this area of administrative law will be cleared to a large extent.

Ricki Rhodarmer Tigert

Ia See note 17 supra. 